\title{
Implementation Of Complete Systematic Land Registration (PTSL) In The Village Of Tanjungharjo, Ngaringan Sub- District, Grobogan District
}

\author{
Edo Iranda Novatama ${ }^{1}$ and Umar Ma'ruf ${ }^{2}$
}

Abstract. The purpose of this study was to: 1) To determine and analyze Systematic implementation of the Complete Systematic Land Registration in Village of Ngaringan, Tanjungharjo Subdistrict, Grobogan District 2) To identify and analyze the obstacles faced in the Complete Systematic Land Registration in Village of Ngaringan, Tanjungharjo Subdistrict, Grobogan District. The data used in this study are primary data, secondary data and data that can support tertiary study, which was then analyzed by sociological methods.

Based on the results of data analysis concluded that: 1) Implementation of PTSL by adjudication teams dominate in their respective fields in their duties, their dexterity of team officials adjudication PTSL in performing their duties which is always ready to be in place basecamp / office Adjudication Team in terms of running activities, the cooperation with the village as well as their facilities and infrastructure such as the computerized system so that it becomes a factor that support the implementation of land registration through PTSL program. Rural communities in the program areas PTSL responded well and was very happy to participate as the program participants as evidenced by the demand from the public to register as a participant PTSL program that exceeds that of the set target. 2) Obstacles that occur in the field, among others, lack of knowledge of the importance of data collection for the certificate issuance process, so people tend to underestimate completeness impressed application file such as ID cards and SPPT (Income Tax Payable). In addition proof of ownership of the land acquired is minimal, so that the necessary statements and testimony. Then the location of Block SPPT on the rights object not fit image map Ricikan Block PBB Layout object existing rights in Block SPPT incompatible with image map Ricikan Block PBB, making it difficult for the task force juridical data collectors in determining the location of the object that right.

Keywords: PTSL; Implementation; Obstacles.

\section{Introduction}

National development is a series of efforts of sustainable development covering the entire life of the community, the nation and the State to carry out the task of realizing national development as stated in the Preamble to the Constitution of 1945, which protect all the people and the country of Indonesia, promote the general welfare, educating the nation and participate in implementing world order based on freedom, lasting peace and social justice. ${ }^{3}$

Article 33 paragraph (3) of the Constitution of the Republic of Indonesia of 1945 became the basis for the establishment of BAL, as mentioned in article 2 paragraph (1) $B A L$, namely: "On the basis of the provisions in article 33 paragraph 3 of the Constitution and other things as referred to in article 1, earth, water and space angakasa, including the wealth of the country, as all the people of Indonesia

1 Master Notary Law Student, Sultan Agung Islamic University Semarang, Email novatama07@gmail.com

${ }^{2}$ Lecturer of Faculty of Law, Sultan Agung Islamic University Semarang

${ }^{3}$ Ali Chomzah, 2004, Hukum Agraria Pertanahan Indonesia, Jilid 2, Prestasi Pustaka, Jakarta, p. 21. 
kekuaasaa organization. Article above merupaka constitutional basis for the establishment of National Land Law, which beriss that state-based rule the earth, water and natural resources contained therein, and the mastery goal is to totally for prosperity of the people. ${ }^{4}$

Complete Systematic Land Registration as defined in Article 1 paragraph (2) of Regulation of the Minister of Agriculture and Spatial Planning / Head of National Land Agency Number 6 of 2018 is a land registration activities for the first time carried out simultaneously covering all the objects of registration of land which has not been registered in the the village area or other name on par with it in order to provide legal certainty and legal protection of land rights of the people in a fair and equitable, and promote economic growth in general and the people's economy in particular, need to be accelerated Complete Systematic Land Registration in all the territory of the Republic of Indonesia. Organized systematic land registration initiated by the government on a long-term work plan and annual and implemented region-areas designated by the Minister of Agriculture or the National Land Agency. These activities include the systematic adjudication, cadastral survey, providing facilities and office equipment Land and dissemination of information about the benefits of land registration through counseling.

Not all people have the knowledge about how to register the land, how to get certified, and how to process the application of the National Land Agency land titles. Besides about land titling, people are still many who do not understand how to process a complete systematic land registration. Whereas the public had the opportunity through the legal security of the land is systematically complete the registration process.

Grobogan, is one of regencies in Central Java province. Center city was in Purwodadi district. Precisely in Purwodadi village, geographically, Grobogan area located between 11015 'E - 111 25'BT and 7 LS- 7 30' LS with the soil conditions in the form of lime mountains areas, hills and plains in the middle. Administratively Grobogan consists of 273 villages and 7 village spread over 19 districts.

Sub-district of Ngaringan formed under Act No. 13 of 1950 on the Establishment of areas within the District Central Java Province, sub-district has an area of $116.72 \mathrm{~km}$ with a population of 2010, is divided administratively into 399 RT 91 RW and 12 villages, which is one of the village became the object of study authors that Tanjungharjo village. Village of Tanjungharjo majority of farmers to soil conditions such as paddy fields and agricultural land with an area of 2800 ha and consists of 11 villages admnistrative RT 46 and 13 RW. Much of the land owned by residents of the village does not have land certificates even though the land certificate is a form of legal certainty to land in the right. Based on the above background, the authors carry out research and study the problems concerning the complete systematic land registration following the problems that occur in the field as an ingredient preparation International Journal entitled: " Implementation Of Complete Systematic Land Registration (PTSL) In The Village Of Tanjungharjo, Ngaringan Sub-District, Grobogan District".

\section{Research methods}

The method used in this research is descriptive analytical which aims to unravel the facts to obtain an overview, about the existing problems, analyzing and reviewing the legal facts to determine how problems implementation of land registration system is

\footnotetext{
4 Urip Santoso,2016, Pejabat Pembuat Akta Tanah Perspektif Regulasi,Wewenang, dan Sifat Akta, Karisma Putra Ulama, Jakarta, p. 2
} 
complete in the Grobogan district especially in village of Tanjungharjo, Ngaringan subdistrict if it is appropriate the existing regulations and how the role of the collaboration between villagers, the village and the National Land Agency and whether it is still there any obstacle to the implementation of the program related to Complete Systematic Land Registration System.

The research is a qualitative legal research the law by using Juridical sociological approach. Juridical sociological which is done by researching library materials is a secondary data and examines the primary data (data obtained directly from the community). In this study will look at the real situation in the field on the implementation of Complete Systematic Land Registration System Based Agricultural Ministerial Regulation No. 6 of 2018 in the village of Tanjungharjo, Ngaringan subdistrict, Grobogan district and obstacles that occur in the field.

\section{Results And Discussion}

\subsection{Implementation of Complete Systematic Land Registration System in Village of Ngaringan, Tanjungharjo Sub-district, Grobogan District}

Based on the results of the study Implementation of Complete Systematic Land Registration System initiated by the government in order to improve land management arrangement through the acceleration of the systematic land registration and financed by the government which was funded by a World Bank loan. Because in a society that PTSL program given the ease of registering land and the cost has been borne by the government as well as the completion of the land registration process quickly. In the implementation of the settlement process yourself PTSL program are not allowed to exceed 1 (one) year budget.

In the implementation of land registration through the PTSL program community said he paid the sum of 600.000, - (six hundred thousand rupiah) to the village at the time the certificate is already finished and from the village also explained that the cost of some 600,000, - (six hundred thousand rupiah) the previously informed to the participants of PTSL program, the cost does not include the imposition BPHTB for participants that addresses provisions. In determining the cost of the deal was also discussed in advance to the participants of PTSL. The village was explained also that the costs for the purposes of stamp duty, land boundary markers, a copy of the data, accommodation and heir statement.

It is in conformity with the principle of land registration in Article 2 of Government Regulation No.24 of 1997, a reasonable principle that meant affordability for those in need, particularly having regard to the needs and capabilities of economically weak groups in the implementation of programs in the Ngaringan sub-district participants of PTSL program hit with the issue of costs to register their land so that with the PTSL program people felt helped in registering the land ${ }^{5}$.

Based on the research results to the respondents / participants of PTSL, they all accept and are not concerned about the costs incurred in the care of it, because the respondents / participants of PTSL considers that the costs incurred in taking care of the land registration include cost and process of completion quickly and if there are difficulties in care assisted by the village, whereas if the registration of other land rather expensive as land registration via SMS (Certification Bulk Governmental) which

\footnotetext{
${ }^{5}$ Adrian Sutedi, 2011, Seritikat Hak Atas Tanah, Jakarta : Sinar Grafika, p. 85
} 
costs up to 1 (one) million or register the land itself (through routine) too expensive so did not have money to take care of it yet again the long turnaround times.

From the results of the implementation of systematic land registration through PTSL program participants of PTSL program given evidence in the form of certificates of property rights over land. So with the ownership certificate as proof of the right to have provided legal certainty and legal protection to rights holders on the ground so that it can easily be proven himself as the holder of the relevant right. In addition, people also have to understand the usefulness of the certificate at any time if they cost money then the certificate can be used as collateral at the Bank to obtain credit as working capital. According to the opinion held respondents the land registry is to obtain evidentiary tool of the legal acts on the ground. The evidence referred to is the certificate that includes mention of the legal actions and the owner's name now is receiving or obtaining right transition.

The registration of land through PTSL program is in conformity with the opinion that at the end of the implementation participants are given proof of rights in the form of certificates of land titles so that participants acquire tools of PTSL strong evidence of the existence of legal acts on the ground ${ }^{6}$.

\subsection{Obstacles In the Complete Systematic Land Registration System in Village of Ngaringan, Tanjungharjo Sub-district, Grobogan District}

Even before the implementation of land registration through PTSL program starts has made efforts or efforts to revitalize the implementation went smoothly as expected, but in practice still met the multiple barriers faced by the Adjudication Team PTSL. The obstacles faced by the Adjudication Team in the implementation of the Land Registration In Systematic Complete in Village of Ngaringan, Tanjungharjo Sub-district, Grobogan District is as follows:

- Lack of Public Knowledge the importance of documenting the lack of knowledge of the importance of data collection for the certificate issuance process, so people tend to underestimate completeness impressed application file such as ID cards and SPPT (Income Tax Payable). In addition proof of ownership of the land acquired is minimal, so that the necessary statements and testimony. This is to cope with sought as much as possible participants of PTSL program to meet these requirements, if the requirements are not complete yet also then made a statement from the local village chief who can confirm the completeness of the evidence is not yet available.

- Rights Object layout At Block SPPT not fit image map Ricikan Block PBB. The layout object existing rights in Block SPPT incompatible with image map Ricikan Block PBB, making it difficult for the task force juridical data collectors in determining the location of the object that right. The way to overcome that is to ask the truth lies the rights object to the applicant / LMPDP program participants and the local village and made a sketch of the corresponding location of the object image and reality.

\section{Closing}

\subsection{Conclusion}

6 S. Rowton Simpson, Land \& Registration, Cambridge, University, $1976: 260$ in A. P. Parlindungan, Pendaftaran Tanah Di Indonesia, Op. Cit., p. 9. 
- In the implementation of land registration through the PTSL program community said he paid the sum of 600.000, - (six hundred thousand rupiah) to the village at the time the certificate is already finished and from the village also explained that the cost of some $600,000,-$ (six hundred thousand rupiah) the previously informed to the participants of PTSL program, the cost does not include the imposition BPHTB for participants that addresses provisions. In determining the cost of the deal was also discussed in advance to the participants of PTSL. The village was explained also that the costs for the purposes of stamp duty, land boundary markers, a copy of the data, accommodation and heir statement. It is in conformity with the principle of land registration in Article 2 of Government Regulation No.24 of 1997, a reasonable principle that meant affordability for those in need, particularly having regard to the needs and capabilities of economically weak groups in the implementation of programs in the Ngaringan sub-district participants of PTSL hit with the issue of costs to register their land so that with the PTSL program people felt helped in registering the land.

- Based on the research results to the respondents / participants of PTSL, they all accept and are not concerned about the costs incurred in the care of it, because the respondents / participants of PTSL considers that the costs incurred in taking care of the land registration include cost and process of completion quickly and if there are difficulties in care assisted by the village, whereas if the registration of other land rather expensive as land registration via SMS (Certification Bulk Governmental) which costs up to 1 (one) million or register the land itself (through routine) too expensive so did not have money to take care of it yet again the long turnaround times.

- Lack of public knowledge the importance of documenting the lack of knowledge of the importance of data collection for the certificate issuance process, so people tend to underestimate completeness impressed application file such as ID cards and SPPT (Income Tax Payable). In addition proof of ownership of the land acquired is minimal, so that the necessary statements and testimony. This is to cope with sought as much as possible participants of PTSL program to meet these requirements, if the requirements are not complete yet also then made a statement from the local village chief who can confirm the completeness of the evidence is not yet available.

\subsection{Suggestion}

Based on the conclusions from the above results, given the importance of land registration that aims to provide legal certainty and legal protection for rights holders, the authors suggest the following:

- People are expected to be more orderly in files meets the program requirements PTSL.

- Extension by the Adjudication Team in order to be maximized because the target completion time PTSL short program so that the village in search for data to be no trouble.

- The government through the District Land Office of Grobogan in PTSL program so that it could be further enhanced and held again to make the process of registration of land in areas of land that have not been certified because the program is helping people in the land registry. 


\section{JURNAL AKTA}

\section{References}

[1] Abdul Wahab, Solichin, 2008, Pengantar Analisis Kebijakan Publik, Malang: UMM Press

[2] Bachtiar Effendi, 1993, Pendaftaran Tanah di Indonesia dan Peraturan Pelaksanaannya, Bandung : Alumni

[3] Boedi Harsono,2002, Menuju penyempurnaan hukum tanah nasional dalam hubunugannya dengan TAP MPR RI IX/MPR/2001, Univesitas Trisakti, Jakarta

[4] Boedi Harsono, 2008, Hukum Agraria Indonesia: Sejarah Pembentukan Undangundang Pokok Agraria, isi dan Pelaksanaannya, Djambatan, Jakarta.

[5] Winamo, Budi, 2002, Kebijakan Publik. Teori, Proses, dan Studi Kasus. Cetakan Kedua. Jakarta: Kencana

[6] Chomzah, Ali Achmad, 2004, Hukum Agraria Pertanahan Indonesia, Jilid 2, Prestasi Pustaka, Jakarta

[7] Djoko Prakoso dan Budiman Adi Purwanto, 1985, Eksistensi Prona Sebagai Pelaksanaan Mekanisme Fungsi Agraria, Jakarta : Ghalia Indonesia

[8] H. M Arba, 2015, Hukum Agraria Indonesia,Sinar Grafika, Jakarta

[9] Mariam Darus Badrulzaman, 1997, Mencari Sistem Hukum Benda Nasional, Bandung: alumni

[10] Sahnan, 2016, Hukum Agraria Indonesia, Setara Press, Malang 